\title{
Community based needs assessment in an urban area; A participatory action research project
}

\author{
Saeid Sadeghieh Ahari ${ }^{1}$, Shahram Habibzadeh ${ }^{2}$, Moharram Yousefi ${ }^{3}$, Firouz Amani ${ }^{1}$ and Reza Abdi ${ }^{4}$
}

\begin{abstract}
Background: Community assessment is a core function of public health. In such assessments, a commitment to community participation and empowerment is at the heart of the WHO European Healthy Cities Network, reflecting its origins in health for all and the Ottawa Charter for Health Promotion. This study employs a participation and empowerment plan in order to conduct community assessment.

Methods: The method of participatory action research (PAR) was used. The study was carried out in an area of high socio-economic deprivation in Ardabil, a city in the northwest of Iran, which is currently served by a branch of the Social Development Center (SDC). The steering committee of the project was formed by some university faculty members, health officials and delegates form Farhikhteh non-governmental organization and representatives from twelve blocks or districts of the community. Then, the representatives were trained and then conducted focus groups in their block. The focus group findings informed the development of the questionnaire. About six hundred households were surveyed and study questionnaires were completed either during face-to-face interviews by the research team (in case of illiteracy) or via self-completion. The primary question for the residents was: 'what is the most important health problem in your community? Each health problem identified by the community was weighted based on the frequency it was selected on the survey, and steering committee perception of the problem's seriousness, urgency, solvability, and financial load.
\end{abstract}

Results: The main problems of the area appeared to be the asphalt problem, lack of easy access to medical centers, addiction among relatives and unemployment of youth. High participation rates of community members in the steering committee and survey suggest that the PAR approach was greatly appreciated by the community and that problems identified through this research truly reflect community opinion.

Conclusions: Participatory action research is an effective method for community assessments. However, researchers must rigorously embrace principles of mutual cooperation, respect for public ideas, and a robust belief in community empowerment in order to pave the way for responsible and active citizen participation in the various stages of research.

\section{Background}

Community-based participatory research (CBPR) has been identified as a key strategy for effectively reducing health disparities in underserved communities [1]. Assessing the health of a community through CBPR was identified as one of the core functions of public health in the Institute of Medicine's The Future of Public Health [2]. The Future of Public Health (1988) recommended that local public health agencies should "regularly and systematically

\footnotetext{
* Correspondence: s.habibzadeh@arums.ac.ir

${ }^{2}$ Department of Internal Medicine, Ardabil University of Medical Sciences, University street, 5615746765, Ardabil, Iran

Full list of author information is available at the end of the article
}

collect, assemble, analyze, and make available information on the health of the community, including statistics on health status, community health needs, and epidemiologic and other studies of health problems [3]. However, even when assessments were completed, policy development and assurance mostly did not follow [4,5].

Strong historical roots of assessment can be found in England. John Graunt (1620-1674), an Englishman, is credited to be among the first demographers. His Natural and Political Observations upon the Bills of Mortality written in 1662 demonstrated that there was regularity in mortality and survivorship figures. Yet, William Farr, appointed the first "Compiler of Abstracts" at the General

\section{Biomed Central}

(c) 2012 Ahari et al; licensee BioMed Central Ltd. This is an Open Access article distributed under the terms of the Creative Commons Attribution License (http://creativecommons.org/licenses/by/2.0), which permits unrestricted use, distribution, and reproduction in any medium, provided the original work is properly cited. 
Register Office in July 1839, is generally said to be the first to make use of the standardized mortality rate to adjust for differences in age distribution in different subgroups [3].

\section{Community health assessment defined}

Community health assessment should not be confused with clinical needs assessments, which are routinely performed during an initial visit to a medical care provider. Community health needs assessment produces information that is relevant to groups and is not focused on the medical needs of individuals so that treatment plans can be developed accordingly. Furthermore, community health needs assessment should not be confused with assessment of disease prevention services. Since health is not seen merely as the absence of disease, community health assessment, therefore, focuses on general wellbeing. Of course, in many cases, disease prevention and promotion of general health overlap [6]

Definitions of community health assessment (CHA) widely vary. While some definitions focus on data collection and analysis, others highlight the use of assessment data to develop objectives and action plans for health improvement [3]. A straightforward definition for CHA is "collecting and analyzing, and using data to educate and mobilize communications, develop priorities, garner resources, and plan actions to improve public health [7]. In this article, we use the term Community Health Assessment (CHA) to describe both the process and the product of assessment, in that population health data are essential to both CHA's process and products. We identify the major components of CHA as community engagement, data access, data analysis, and interpretation.

\section{Community participation and empowerment}

Participation by local households would require optimal community engagement [8]. Assessment partnerships are encouraged in Healthy People 2010 and in state-level public health improvement plans such as Healthiest Wisconsin 2010: A Partnership Plan to Improve the Health of the Public [9]. A commitment to community participation and empowerment is at the heart of the WHO European Healthy Cities Network (WHOEHCN), reflecting its origins in health for all and the Ottawa Charter for Health Promotion [10]. Health promotion works through concrete and effective community action in setting priorities, making decisions, planning strategies and implementing them to achieve better health. At the heart of this process is the empowerment of communities, their ownership and control of their own endeavors and destinies [11]. The subsequent Jakarta Declaration (WHO, 1997) reinforces this focus, giving priority to increasing community capacity and empowering individuals. It emphasizes the necessity of participation, with actions being carried out by and with people, not on or to people [12].

Although rigorous evidence of the effectiveness of community participation in relation to health is limited, community participation is widely accepted to have many important benefits [13]. Key benefits include increasing democracy, mobilizing resources and energy, developing more holistic and integrated approaches, achieving better decisions and more effective services, ensuring the ownership and sustainability of programs, and empowering communities [14].

\section{Participatory action research}

Participatory action research (PAR) is a research process that focuses on improving the quality of service by means of a self-reflecting process of exploring and solving problems $[15,16]$. The basic structure of PAR is an ever increasing spiral process of planning, acting, observing, reflecting, developing theory and re-planning [15]. Participation, collaboration and mutuality of all participants in all levels of research is effective in identifying and defining the problem, planning the research, collecting and interpreting the data, planning and evaluating the intervention and re-evaluating the problem in light of the new information generated from the implemented activities, and, finally, disseminating the information $[17,18]$. PAR works with a community, which is defined as a group of people who share a common interest and not necessarily a common geographical location. Empowerment and social change are important goals of PAR. Equality in sharing control and power are basic values of PAR. Through participation in the research process, disempowered participants are expected to lose their fear, and shame, gain self-confidence, self-esteem and control, and develop an understanding of their own value. PAR is highly relevant for work with oppressed and disempowered communities with self-help groups and for health education $[16,19,20]$. The researchers become essentially facilitators or catalysts, and participants become co-learners in PAR; nobody is considered the expert [20]. Insiders and outsiders work together as equals to solve problems. PAR is subjective and therefore not always neutral [17]. PAR involves commitment from all participants and requires mutual respect, trust, humility, adaptability and a holistic approach to problem solving. Listening, dialogue and negotiating consensus are strategies to achieve mutuality and empowerment. As stated previously, the PAR process is an open process that requires constant revisiting of previous levels with newly generated knowledge from actions taken, which then help to reshape the problem and resolve it at a deeper level [20].

This paper describes a local PAR project to conduct a community health assessment in an urban region of Ardabil, a city in the northwest of Iran. The primary 
goals of this study were to: 1) demonstrate how health related needs could be assessed through a PAR approach to community participation in an urban community inside a developing country; and 2) encourage community groups and non-state organizations to collaborate to conduct health-related research. The broadness of the issue and diversity of community groups, made both goals challenging from the start.

\section{Methods}

\section{Study design and community selection}

A community PAR was conducted drawing on theories of community mobilization, participation, and empowerment. The steps included 1) establishing the Steering Committee 2) deciding on methods 3) identifying trusted and interested people to form Executive Committees 4) transferring knowledge 5) collecting and weighting data and 6) interpreting data and prioritizing needs.

A local requirement that stipulates that any community based program should be based on a formal demand by the community made us choose a potentially demanding area, based on the criteria of 'low socio-economic status', 'an abundance of various health problems', and a persistent demand on the part of the residents for improvement. The existence of a non-state health center and a high probability of participation were other criteria for choosing this location. At a meeting with delegates from Health Department of Ardabil Medical University, Mayoralty, and Welfare Organization, an area of about 20000 inhabitants was selected for the study site.

Our research project followed a set of prior activities that were undertaken by some members of the current project with the aim of establishing relationships with the local people and winning their trust. The earlier activities included identifying the trusted individuals, those with philanthropic interests, and those who were interested in local development and trust-building projects. Earlier projects involved repairing small open sewer canals, lighting pathways, holding leisure time classes, building sport teams, allocating library space inside the non-state health center of the region, and providing consultation services. All of the above services were made possible through cooperation between the community representatives and non-state organization agents, who managed to involve and attract the attention of the highest authority of the province in the process.

These successful experiences paved the way for this study. The research committee examined the profiles of the trusted and interested people in voluntary philanthropic activities and outlined the study procedures. Twelve Executive Committees were formed by representatives from 12 Blocks that were selected after considering physi- cal texture and pathways following the blocking system of local community development center.

The most important challenge of this study was to encourage academic researchers and officials of health system to believe in the fact that people can participate in health domain research and be empowered to help conduct health research more effectively.

\section{Involving the community development center and selecting executives}

In order to encourage the Community Development Center (CDC) of Ardabil to participate in this study, the general outline was discussed with CDC officials, agents from Farhikhteh non-state organization, and local people, during three 2-hour face to face meetings. Finally, the Executive Team of research project was decided mostly from among the local people and a few number of university colleagues. An attempt was made to select the majority of Executive Team members of the study from among the non-state organizations and local people. The ratio of the university colleagues to other members was 1 to 7 . The members of the instruction, documentation, supervision, coordination, interview, and enquiry teams were selected from among the community members of CDC and the Farhikhteh institute. Rigorous care was taken to limit the role of the academic members to instruction and other technical aspects and much of the research task were delegated to the community groups in spite of numerous difficulties.

\section{Knowledge transfer and empowerment}

The different methods of community assessment were presented through lectures to all members of the Steering Committee. The group preferred the 'focus group' technique to the other presented methods. The members of the project Executive Team and the representatives of the twelve blocks, who were selected from among interested people based on the documents of the Social Research Center, attended focus group workshops for two months. In addition, a questionnaire designing workshop and the data entering methods were hold for the community members of the project. The instruction prepared members for full participation; in practice, much of the job was delegated to ordinary members of the Executive Committees.

\section{Method of data collection}

The trained community agents of the Executive Committees held group discussions in the twelve blocks with an average attendance of 8 to 14 neighborhood residents with the retention rate of about $70 \%$. On the whole, three group discussions were held in every block by agents who were fluent in both Turkish and Persian. ${ }^{1}$ 
The invited people included local retailers, state employees, housewives, pensioners, trustees, and active youth from the local blocks. The people attending the discussions were also supposed to act as facilitators of the research and prepare the community for full participation.

A note-taker recorded the details of every discussion. The workshops took place in April through May, 2006. The venues for the workshops were decided based on the convenience of each individual group and included the neighbor's homes, local mosques or CDC rooms. During the workshops, the purpose and process of the research was thoroughly explained.

The research process was started with the following statement: "what is the most important problem in your community's health?”. The agents were asked to tell people that "As a member of our community, we want to understand the problems better. It is necessary to know the answer to this question according to your priorities, so that we can suggest an appropriate intervention to health and other officials, and then implement the intervention, and assess the results of our efforts."

From the beginning, it was made clear to the community that health system officials and relevant domains were expected to allocate considerable amounts of time and money on an annual basis to improve health condition. However, the main challenge was to decide on the priorities from the perspectives of the locals.

Each block team was given the mission to discover the most important problems in their community.

After finishing the workshops, the results were reported to the Steering Committee by the representatives of the groups. The final procedure was agreed to by the Steering Committee with the cooperation of agents of Farhikhteh Institute and representatives of twelve local areas.

Subsequently, in order to assess the needs from the perspectives of the households of the blocks, the Steering Committee planned more workshops to empower the community groups to design the questionnaire and conduct interviews. Three 1-day workshops were planned and implemented in July through August, 2006.

The Steering Committee, representatives of twelve blocks and Farhikhteh institute agreed on a questionnaire which included 60 yes-no items. The items were related to the general problems of local people such as health, security, economy, employment, and education. Subsequently, a final orientation session was held for all the local interviewers to practice completing the questionnaire.

The community interviewers of 12 local areas and their supervisors, from among the members of the Executive Committees interviewed 30 households from the 12 blocks and repeated it after a 14-day interval in order to check the reliability of the instrument, which was found to be 0.76 .
Six hundred households were interviewed in September 2006. The target households were selected through cluster random sampling using the CDC database. Considering the population $(20,000)$ and the average number of family members (4.3) in Iran [20], 600 households equaled about $15 \%$ of the households. It should be noted that the demographic information of the participants was not systematically gathered. The supervisors examined the daily delivered questionnaires and randomly checked some households for quality assurance purposes.

\section{Method of data analysis}

During the Steering Committee's meetings, the necessity of including diverse groups of people was discussed. The best method of implementing community assessment was also discussed. Finally, the Steering Committee decided to apply a mixed model containing surveys and focused group discussion in the local areas.

The first set of data was produced following analysis of the priorities offered by 12 local groups which represented each block. Then, face-to-face interviews were carried out with [almost all] 600 households of the selected area, to create a second dataset. With consistent supervision and training, the community groups entered the data into the computer as planned. They cooperated with a statistician to analyze the data. Finally, the output of the data which comprised five main problems from the perspective of 600 households was produced.

\section{Ethical considerations}

This study was approved in the research committee of Ardabil University of Medical sciences, which considers and verifies the research proposals both academically and ethically. It should also be noted that participation in this project has been voluntary for all the community representatives and the agents of Farhikhteh institute of Ardabil. In the first meeting, their option to leave or continue the study was explained to them formally at the beginning and during the study. The researcher after acknowledging their participation in the project ensured the privacy of the data. Additionally, an attempt was made to employ both female and male colleagues to observe the religious and cultural norms and values.

\section{Results}

In the first stage of analysis, the needs of 12 local areas were identified. The number of identified needs for the neighborhoods varied from 8 to 24 . As it can be seen in Table 1, the five prioritized problems for each neighborhood are related but not limited to the health domain.

In Table 2, the results of the analysis of frequency of the problems, from the point of view of 600 households, are displayed. 
Table 1 The leading priorities of local areas

\begin{tabular}{|c|c|c|c|c|c|}
\hline Blocks & Priority 1 & Priority 2 & Priority 3 & Priority 4 & Priority 5 \\
\hline 1 & Littered neighborhood & The asphalt problem & Open sewer & $\begin{array}{l}\text { Poor or no } \\
\text { Snowplowing in the } \\
\text { winter }\end{array}$ & $\begin{array}{c}\text { The problem of neighborhood } \\
\text { with iron sellers market }\end{array}$ \\
\hline 2 & The asphalt problem & $\begin{array}{c}\text { Littered } \\
\text { neighborhood }\end{array}$ & $\begin{array}{c}\text { Inefficient rubbish collection } \\
\text { system }\end{array}$ & $\begin{array}{l}\text { Darkness of the } \\
\text { neighborhood at night }\end{array}$ & Open sewer \\
\hline 3 & The asphalt problem & $\begin{array}{l}\text { Inefficient rubbish } \\
\text { collection system }\end{array}$ & The problem of water canals & Open sewer & Lack of closed sewer system \\
\hline 4 & $\begin{array}{c}\text { Poor or no Snowplowing in } \\
\text { the winter }\end{array}$ & $\begin{array}{l}\text { Inefficient rubbish } \\
\text { collection system }\end{array}$ & The asphalt problem & Water shortage & $\begin{array}{c}\text { Absence of house plaques and } \\
\text { alley names }\end{array}$ \\
\hline 5 & The asphalt problem & Water shortage & $\begin{array}{l}\text { Inefficient rubbish collection } \\
\text { system }\end{array}$ & $\begin{array}{l}\text { Electrical current } \\
\text { Instability }\end{array}$ & $\begin{array}{l}\text { Lack of public transportation } \\
\text { vehicles }\end{array}$ \\
\hline 6 & The asphalt problem & $\begin{array}{l}\text { High unemployment } \\
\text { rate }\end{array}$ & $\begin{array}{l}\text { Inefficient rubbish collection } \\
\text { system }\end{array}$ & Open sewer & Littered neighborhood \\
\hline 7 & The asphalt problem & $\begin{array}{l}\text { High unemployment } \\
\text { rate }\end{array}$ & inefficient rubbish collection & Open sewer & Littered neighborhood \\
\hline 8 & The asphalt problem & $\begin{array}{l}\text { High unemployment } \\
\text { rate }\end{array}$ & Littered neighborhood & $\begin{array}{l}\text { Darkness of } \\
\text { neighborhood at night }\end{array}$ & The stench of streams \\
\hline 9 & littered neighborhood & Water shortage & $\begin{array}{l}\text { Lack of welfare, education } \\
\text { and recreational facilities }\end{array}$ & Littered neighborhood & High unemployment rate \\
\hline 10 & $\begin{array}{l}\text { lack of welfare, education } \\
\text { and recreational facilities }\end{array}$ & $\begin{array}{l}\text { Lack of public } \\
\text { transportation } \\
\text { vehicles }\end{array}$ & $\begin{array}{l}\text { Defective slope of water } \\
\text { canals }\end{array}$ & $\begin{array}{l}\text { Lack of access to } \\
\text { mosque and Basij base }\end{array}$ & The asphalt problem \\
\hline 11 & The asphalt problem & $\begin{array}{l}\text { The problem Of } \\
\text { water canals }\end{array}$ & $\begin{array}{l}\text { Financial problems and } \\
\text { destitution of people }\end{array}$ & $\begin{array}{l}\text { High unemployment } \\
\text { rate }\end{array}$ & $\begin{array}{c}\text { Sanitary/health problems of } \\
\text { the region }\end{array}$ \\
\hline 12 & $\begin{array}{c}\text { Inefficient rubbish collection } \\
\text { system }\end{array}$ & $\begin{array}{l}\text { High unemployment } \\
\text { rate }\end{array}$ & $\begin{array}{c}\text { Darkness of neighborhood } \\
\text { at night }\end{array}$ & The housing problem & $\begin{array}{c}\text { Poor or no Snowplowing in } \\
\text { the winter }\end{array}$ \\
\hline
\end{tabular}

In the next stage of research, the Steering Committee decided on some more criteria to produce more practical results. The four criteria that were agreed on were: seriousness, urgency, solvability, and financial burden of the problems, which received weights (quotients) of 8.6, $7.5,5.5$, and 4.8 , respectively. The frequency criterion received a weight of 6.8 . To arrive at these weights, all 30 members of the Steering Committee assigned a weight score of 1-10 to the above five criteria and then the results were averaged out.

When the five criteria and relevant weights were decided, the Committee met again and all 30 members provided a value number of 1-100 to each problem (e.g. lack of adequate pathway lighting) in terms of its seriousness, urgency, solvability, and financial burden. Then, the five values were multiplied by the relevant weight to yield the final score for each problem which appears in Table 3.

\section{Discussion}

This participatory action research demonstrated that the availability of trusted and philanthropic people could be very helpful at the beginning of the project. This study also revealed that when assessment of the health problems of a community is carried out, other social problems may be observed that influence the community's general health. As confirmed by the data in Table 3, health is influenced by an array of social factors $[21,22]$.
Working "with people and for people" during the project indicated that efforts for establishing relationships, empowerment, trusting key roles to people, and involving them in health research can pave the way for high community participation. However, convincing people to trust and join the project was a real challenge at the beginning, which was resolved by the perseverance and negotiation of the certain members of the Steering Committee with the trusted group.

The results of study clarified that in working with the community, researchers should ignore their presuppositions, and let participants discover their own problems and needs, which is a crucial step in empowerment.

Participatory researchers in developing countries such as Iran allocate most of their energy to coping with local rules, getting the approval of participatory research projects, and facing objections from traditional researchers.

This study demonstrated that active community participation can be achieved if the following conditions are met:

1. Acknowledging the key role of people in designing and actually conducting studies;

2. Providing adequate training in research methods;

3. Building trust and empowerment;

4. Seriously taking the community's viewpoint into account;

5. Crating a sense of responsibility in the community; 
Table 2 The rank of problems according to the frequency from the viewpoint of people (calculated as the average number of people in any 100 people who mentioned the problem)

\begin{tabular}{lll}
\hline Rank & The problem & Frequency \\
\hline 1 & lack of easy access to health and medical center & 97 \\
2 & Existence of mechanical repair shop in the local area & 96.4 \\
3 & lack of mosques or little people's activity in the mosques & 87 \\
4 & Lack of parking lots & 83.3 \\
5 & Lack of interest-free loan fund in the local area & 83 \\
6 & Lack of fruit/vegetable market and department stores & 78 \\
7 & Inappropriate rubbish disposal & 67.8 \\
8 & Poor provision of subsidized milk & 67.7 \\
9 & littered neighborhood & 66.8 \\
10 & The asphalt problem & 66.6 \\
11 & Absence or shortage of sport facilities & 65 \\
12 & The problem of pathways lightings & 62.7 \\
13 & Absence or remoteness of feminine high school & 61.8 \\
14 & The shortage of public transportation vehicles & 54.8 \\
15 & Disturbance of hooligan youth in the local area & 54.4 \\
16 & Unemployment of youth & 45.5 \\
17 & The problem of old water pipes and water shortage in the local area & 34.2 \\
18 & Insecurity when leaving homes & 32.4 \\
19 & Addiction among relatives & 30.4 \\
20 & Low economic welfare indices & 29 \\
21 & Enormous cost of children's high education & 25.4
\end{tabular}

Table 3 Final prioritization of the problems of urban area under study

\begin{tabular}{lll}
\hline Rank & The problem & Total score \\
\hline 1 & The asphalt problem & 2508.3 \\
2 & Lack of easy access to health and medical centers & 2317.2 \\
3 & Addiction among relatives & 2315 \\
4 & Unemployment of youth & 2285.8 \\
5 & Inappropriate rubbish disposal & 2248.7 \\
6 & Absence and remoteness of feminine high school & 2128.1 \\
7 & The problem of pathways lightings & 2102.4 \\
8 & Absence or shortage of sport facilities & 2004.2 \\
9 & Existence of mechanical repair shop in the local area & 1984.2 \\
10 & Lack of parking lots & 1914.2 \\
11 & The shortage of public transportation vehicles & 1894.9 \\
12 & Lack of fruit/vegetable market and department stores & 1883.4 \\
13 & littered neighborhood & 1859.7 \\
14 & Low economic welfare indices & 1770.5 \\
15 & lack of interest-free loan fund in the local area & 1765.1 \\
16 & Poor provision of subsidized milk & 1653 \\
17 & Enormous cost of children's high education & 1632.3 \\
18 & Disturbance of hooligan youth in the region & 1624.3 \\
19 & Lack of mosques or their low level of activity & 1501.3 \\
20 & The problem of old water pipes and water shortage in the local area & 1485.8 \\
21 & Insecurity when leaving the homes & 1453.8 \\
\hline
\end{tabular}


6. Involving a non-state organization in the research as a bridge between the community and the state; and

7. Communicating research results with participants in public forums and newspaper articles.

However, this study could have been more useful if the following limitations were not present. In the first place, we could not secure a full participation of authorities from non-health departments. Secondly, the demographic details was not gathered which could have enriched the interpretation of the data. Thirdly, we could not attract a proportionate participation of women due to cultural constraints. Finally, our project was the first in type in the region both for the members of the steering committee and also the general participants, which frequently resulted in slowing the procedure.

\section{Conclusions}

PAR is very applicable for community assessment. However, researchers must rigorously take into account the caveats of mutual cooperation, respect for public ideas, and a robust belief in community empowerment in order to pave the way for people to feel responsible and actively take part in the various stages of research.

\section{Endnotes}

The native language of people in Ardabil Province is Turkish, while the official language is Persian. During late decades, the local people have used Turkish for oral conversation and Persian for written communication. Only a quite small number of people are able to read and write in Turkish. However, in accordance with the current traditions and convenience of region, the group discussions were performed in Turkish, but recorded in Persian.

\section{Abbreviations \\ SDC: Social Development Center; CBPR: Community-Based Participatory Research; CHA: Community Health Assessment; IOM: Institute of Medicine; WHOEHCN: WHO European Healthy Cities Network; PAR: Participatory action research.}

\section{Acknowledgements}

We express our gratitude to all residents of the region under study who even sometimes received us in their homes. Moreover, we should thank the community agents of the Steering and the Executive Committees of the project which aided us generously and taught us a lot. Finally, we appreciate Research Department of Ardabil University of Medical Sciences that financially supported this project.

\section{Author details}

'Department of Community Medicine, Ardabil University of Medical Sciences, University street, 5615746765, Ardabil, Iran. ${ }^{2}$ Department of Internal Medicine, Ardabil University of Medical Sciences, University street, 5615746765, Ardabil, Iran. ${ }^{3}$ Empowerment Institute, Bakeri street, 5624849658 Ardabil, Iran. ${ }^{4}$ Department of ELT, Faculty of Humanities, University of Mohaghegh Ardabili, University Street, 5619911367, Ardabil, Iran.

\section{Authors' contributions}

All authors made a substantial contribution to and the design and implementation of the study and were involved in drafting and reviewing the manuscript. All authors have read and approved the final manuscript.

\section{Competing interests}

The authors declare that they have no competing interests.

Received: 6 October 2011 Accepted: 7 March 2012

Published: 7 March 2012

\section{References}

1. Pazoki R, Nabipour I, Seyednezami N, Imami SR: Effects of a communitybased healthy heart program on increasing healthy women's physical activity: a randomized controlled trial guided by Community-based Participatory Research (CBPR). BMC Public Health 2007, 7:216.

2. Fararouei M, Robertson C, Whittaker J, Sovio U, Ruokonen A, Pouta A, Hartikainen AL, Jarvelin MR, Hypponen E: Maternal Hb during pregnancy and offspring's educational achievement: a prospective cohort study over 30 years. Br J Nutr 2010, 104(9):1363-1368.

3. Irani P, Bohn C, Halasan C, Landen M, McCusker D: Community health assessment: driving the need for current, easily accessible population health data. J Public Health Manag Pract 2006, 12(2):113-118.

4. Handler A, Issel M, Turnock B: A conceptual framework to measure performance of the public health system. Am J Public Health 2001, 91(8):1235-1239.

5. Rohrer JE, Dominguez D, Weaver M, Atchison CG, Merchant JA: Assessing public health performance in lowa's counties. J Public Health Manag Pract 1997, 3(3):10-15

6. Rohrer JE: Use of published self-rated health-impact studies in community health needs assessment. J Public Health Manag Pract 2009, 15(4):363-366.

7. AssessNow: A collaboration of the Washington State Department of Health and local health jurisdictions. What is Assessment. 2010 [http:// assessnowinfo/assessmenthtml].

8. Pasricha S-R, Vijaykumar V, Prashanth NS, Sudarshan H, Biggs B-A, Black J, Shet A: A community based field research project investigating anaemia amongst young children living in rural Karnataka, India: a cross sectional study. BMC Public Health 2009, 9:59.

9. Zahner SJ, Kaiser B, Kapelke-Dale J: Local partnerships for community assessment and planning. J Public Health Manag Pract 2005, 11(5):460-464.

10. Heritage Z, Dooris M: Community participation and empowerment in Healthy Cities. Health Promot Int 2009, 24(Suppl 1):i45-155.

11. WHO: Ottawa Charter for Health Promotio. Geneva: WHO; 1986.

12. WHO: Jakarta Declaration on health promotion into the 21st century. Rev Panam Salud Publica 1998, 3(1):58-61.

13. Zakus JD, Lysack CL: Revisiting community participation. Health Policy Plan 1998, 13(1):1-12

14. WHO: Community participation in local health and sustainable development, Approaches and techniques. 2002 [http://www.eurowhoint/ _data/assets/pdf_file/0013/101065/E78652pdf].

15. $\bar{M}$ CNiff J: Action Research: Principles and Practic. 1988.

16. Wallerstein $N$, Bernstein E: Introduction to community empowerment, participatory education, and health. Health Educ Q 1994, 21(2):141-148.

17. Schensul JJ: Organizing community research partnerships in the struggle against AIDS. Health Educ Behav 1999, 26(2):266-283.

18. Macaulay AC, Commanda LE, Freeman WL, Gibson N, McCabe ML, Robbins CM, Twohig PL: Participatory research maximises community and lay involvement, North American Primary Care Research Group. BMJ 1999, 319(7212):774-778

19. Brydon-Miller M: Participatory action research: Psychology and social change. J Soc Issues 1997, 53(4):657-666.

20. Marincowitz G: How to use participatory action research in primary care. Fam Pract 2003, 20(5):595-600.

21. McGibbon E, Etowa J, McPherson C: Health-care access as a social determinant of health. Can Nurse 2008, 104(7):22-27.

22. Macleod J, Davey Smith G, Metcalfe C, Hart C: Is subjective social status a more important determinant of health than objective social status? Evidence from a prospective observational study of Scottish men. Soc Sci Med 2005, 61(9):1916-1929. 


\section{Pre-publication history}

The pre-publication history for this paper can be accessed here:

http://www.biomedcentral.com/1471-2458/12/161/prepub

doi:10.1186/1471-2458-12-161

Cite this article as: Ahari et al:: Community based needs assessment in

an urban area; A participatory action research project. BMC Public Health 2012 12:161.

Submit your next manuscript to BioMed Central and take full advantage of:

- Convenient online submission

- Thorough peer review

- No space constraints or color figure charges

- Immediate publication on acceptance

- Inclusion in PubMed, CAS, Scopus and Google Scholar

- Research which is freely available for redistribution 